\title{
Ortaokul Öğretmenlerine Göre Okul Müdürlerinin Liderlik Davranışları İle Öğretmenlerin Örgütsel Bağlılı̆̆ının İncelenmesi ${ }^{1}$
}

\author{
Volkan DEMIR ${ }^{2}$ ve Mehmet DURNALI ${ }^{3}$
}

\section{$\ddot{\mathrm{O} z}$}

$\mathrm{Bu}$ çalışmanın amacı, ortaokul kademesinde çalışan öğretmenlerin görüşlerine göre; okul müdürlerinin liderlik davranışları ile öğretmenlerin örgütsel bağlllık düzeylerini, aralarındaki ilişkiyi ve yordama durumunu tespit etmektir. Çalışmaya 2020-2021 eğitim öğretim yllında Zonguldak ili Ereğli ilçesinde ortaokul kademesinde görev yapan 274 öğretmen katılmıştır. Araştırmada veri toplama aracı olarak okul müdürlerinin liderlik özelliklerini saptamaya yönelik "Okul Liderliği Ölçeği” ve öğretmenlerin okula karşı bağlllıklarını ölçmeye yönelik "Örgütsel Bağlllık Ölçeği”" kullanılmıstır. Elde edilen bulguların analizinde SPSS programı kullanılarak frekans analizi, aritmetik ortalama, Mann Whitney U Testi, Kruskal-Wallis Testi, Korelasyon Analizi ve Regresyon Analizi uygulanmıştır. Çalışmada, okul müdürlerinin liderlik davranışlarına ve öğretmenlerin örgütsel bağlllık düzeylerine ilişkin katılımcı puanları ortalamanın üstünde çıkmıştır. Okul liderliğinin cinsiyet değişkeni üzerinde farklılık gösterdiği tespit edilmiş olup çalışmaya katılan erkek katılımcıların puanlarının kadın katılımcıların puanlarından yüksek çıkmıştır. Öğretmenlerin mesleki kıdemlerine göre okul müdürlerinin liderlik davranış1 ve öğretmenlerin örgütsel bağlllıklarına ilişkin görüşleri fark oluşturmamıştır. Okul müdürlerinin liderlik davranışı ile örgütsel bağlılık arasında pozitif yönde ve orta düzeyde bir ilişki olduğu saptanmıştır. Okul müdürlerinin liderlik davranışı örgütsel bağlılığ1 olumlu ve anlamlı olarak yordamıştır.

Anabtar Kelimeler: Okul Liderliği, Örgütsel Bağl1lık, Okul Müdürleri, Öğretmenler

\section{Investigation of the Secondary School Teachers' Perceptions on Leadership Behaviours} of School Principals and Teachers' Organizational Commitment Levels

\begin{abstract}
The purpose of this study is to investigate of the relationship between secondary school teachers' views on the leadership of school principals and teachers' organizational commitment levels. The study intended to examine how well teachers' views on the leadership of school principals can predict their perceptions of organizational commitment as well. 274 teachers working at the secondary school level in the 2020-2021 academic year in the Ereğli district of Zonguldak province participated in the study. The School Leadership Scale has been used to determine the leadership features of school principals which are used as a data collection tool of the research and the Organizational Commitment Scale has been used to measure the commitment of the teachers to the school. The frequency analysis, arithmetic mean, Mann Whitney U test, Kruskal-Wallis test, correlation analysis, and regression analysis have been implemented by using the SPSS program. As a result of the study, it was determined that teachers' perceptions in the leadership of school principals and their organizational commitment levels were high. It was determined that school leadership differs on the gender variable and it was determined that the scores of the male participants who participate in the research were higher than the female participants. It was determined that the professional seniority of the teachers did not affect their school leadership perceptions and organizational commitment. It was found out that there is a positive and moderate relationship between the leadership behavior of school principals and organizational commitment. Leadership behavior of school principals predicted organizational commitment positively and significantly.
\end{abstract}

Key Words: School Leadership, Organizational Commitment, School Principals, Teachers

\section{Atıf İçin / Please Cite As:}

Demir, V. ve Durnalı, M. (2022). Ortaokul öğretmenlerine göre okul müdürlerinin liderlik davranışları ile öğretmenlerin örgütsel bağglllığının incelenmesi. Manas Sosyal Araştrmalar Dergisi, 11(1), 143-157.

Geliş Tarihi / Received Date: 13.02.2021

Kabul Tarihi / Accepted Date: 23.07.2021

\footnotetext{
${ }^{1}$ Bu makale, Dr. Mehmet DURNALI danışmanlığında, Volkan DEMIR tarafindan gerçekleştirilen yüksek lisans çalışmasının yeni kaynaklar eklenerek geliştirilmesi çabasının bir ürünüdür.

2 Öğretmen - Hatice Erdem Mesleki ve Teknik Anadolu Lisesi, bdvolkandemir@gmail.com

(iD) ORCID: 0000-0003-4501-6826

${ }^{3}$ Doç. Dr. - Zonguldak Bülent Ecevit Üniversitesi Eğitim Fakültesi, durnali@gmail.com

(iD ORCID: 0000-0002-1318-9362
} 


\section{Giriş}

Okulu geliştirmek için geleneksel okul müdürü davranışları yerine etkili liderlik davranışlarına ihtiyaç duyulabileceği görüşü liderlik epistemolojik hareketi içerisinde kendisine gittikçe artan sayıda taraftar bulmaktadır (Yilmaz, 2020, s. 1; Nartgün, Limon ve Dilekçi, 2020, s. 141; Turan, Polatcan ve Cansoy, 2020, s. 59). Okul müdürü liderliğinin, bu hareket içerisinde hâkim paradigma olma noktasında teori ve pratikte ilerlediği ve genişlediği anlaşılmaktadır (Özdemir, 2019, s. 81; Fidan, Ayyıldız ve Kurt, 2021, s. 513; Gökbulut ve Turan, 2021, s. 589). Bu aktüelde bir doğurgu olarak, okullarda görev yapan yöneticilerin liderlik rolünün önemli olduğu düşünülmektedir (Durnalı ve Akbaşlı, 2020, s. 23-54; Çoban, 2021, s. 45-6). Etkili okul müdürlerinden okullarının amaçlarını üst düzeyde gerçekleştirmek için liderlik rollerini sergilemesi beklenir (Durnalı, 2018, s. 1). Liderlik rollerine dayalı bu etkililikler kapsamında, uygun eğitim ortamları oluşturarak öğretmenlerin motivasyonunu arttırma ve okulla ilgili kararları öğretmenler ile paylaşarak öğretmenlerin örgüte olan bağlllık düzeylerini yükseltme örnek olarak verilebilir.

Bu noktada, ögretmenlerin okula olan bağlllıkları sorunsalının günümüzde eğitim bilimleri disiplininde aktüel edimsel bir durumda olduğu araştırmanın örgütsel bağlllıkla ilgili kısmından anlaşılabilir. Bu konunun, eğitim bilimleri alanında ana akım uğraşı olan eğitimin verimli ve etkililiği bağlamında önemli olduğu belirtilebilir. Öğretmenlerin okula bağlllık düzeylerini artırmaya yönelik okul ve eğitim unsurlarının eğitimde bütünlük sağlama noktasında incelenmesi faydalı olabilir. Bu önem temelinde, öğretmenlerin örgütsel bağlılıkları ile okul müdürlerinin liderliği konularının incelenmesi sorunsalı bu çalışmanın odağına yerleştirilmiştir. Bu odağın çerçevesini aşağıdaki sorular çizmektedir.

1. Öğretmenlerin görüşlerine göre; okul müdürlerinin sergilediği liderlik davranışları ve ögretmenlerin örgütsel bağlllık düzeyleri nasıldır?

2. Okul müdürlerinin sergilediği liderlik davranışlarına yönelik öğretmenlerin görüşleri, ögretmenlerin cinsiyetlerine göre istatistiki açıdan anlamlı farklılık göstermekte midir?

3. Okul müdürlerinin sergilediği liderlik davranışlarına yönelik öğretmenlerin görüşleri, öğretmenlerin mesleki kıdemlerine göre istatistiki açıdan anlamlı farklılık göstermekte midir?

4. Öğretmenlerin örgütsel bağlllığına yönelik öz görüşleri, öğretmenlerin cinsiyetlerine göre istatistiki açıdan anlamlı farklılık göstermekte midir?

5. Öğretmenlerin örgütsel bağlllı̆ına yönelik öz görüşleri, öğretmenlerin mesleki kıdemlerine göre istatistiki açıdan anlamlı farklılık göstermekte midir?

6. Öğretmen görüşlerine göre okul müdürlerinin sergilediği liderlik davranışı ile öğretmenlerin örgütsel bağlılığına ilişkin öğretmen görüşleri arasında ilişki var mıdır?

7. Okul müdürlerinin liderlik davranışı öğretmenlerin örgütsel bağlılığını yordamakta mıdır?

\section{Okul Müdürlerinin Liderliği}

Yönetim kavramının temelinde hiyerarşi, disiplin ve kontrol gibi içerikler bulunduğu halde liderliğin içeriğinde, yaratıcılık, risk alma, değerler gibi kavramlar ön planda yer almakta; esas olarak da insanları belirlenen amaçlara yönlendirme konusu önem kazanmaktadır (Arslan, 2009, s. 5). Bu önem izdüşümünde, eğitim-öğretim süreçlerinde yaşanan değişimler okul müdürlerinin liderlik rollerinde de bir değişimi zorunlu kılmıştır. Yukarıdan aşağıya hiyerarşik bir yönetim anlayışına dayalı geleneksel liderlik rolleri, yaşanan değişim süreçleriyle, lider ve onu takip edenler ekseninden styrrlarak, önderlik eden-işbirliği içinde çalışanlar paylaşımına doğru değişmiştir (Beycioğlu ve Aslan, 2012, s. 195).

Liderlik çalışanlara emirler verme davranışlarıyla sınırlı değildir. Liderlik geleneksel anlamı ile hiyerarşik yapıdaki otoriteden farklı değerlendirilmelidir. Otorite altında çalışanlar, üstünün yetkisini kabullendiğinden daha kolay yönetilmeleri mümkün olmaktadır. Bu nedenle yasal otoritesi ile örgütü hedefe yönlendiren bir yöneticinin lider olduğunu söylemek mümkün değildir (Akçakoca ve Bilgin, $2016 \mathrm{~s}$. 2). Etkili liderlik yeteneğini, bir yöneticinin sahip olabileceği en önemli vasıflar arasında kabul etmek mümkündür. Yöneticiler planlama ile karşılaştıkları problemleri çözmeye çalışırken, liderler ise, kendi yol ve yöntemlerini ortaya koyarak örgüt içindeki değişimi gerçekleştirirler (Akyüz, 2002, s. 111). Lider olmay1 başarabilen yönetici, çalışanlarının ihtiyaçlarını, beklentilerini, sorunlarını bilen, empati yeteneği yüksek, bir yandan kurumun amaçlarını gözetirken diğer yandan çalışanlarının iş doyumunu sağlayabilen kişidir (Yllmaz ve Ceylan, 2011, s. 286).

Liderler onu izleyenler ile etkili bir iletişim kurarak onları örgütün amaçları doğrultusunda hedefe yöneltirler. Liderlerin temel özelliği, çalşsanların kendilerini yeterli, bilgili ve güvende hissetmelerini sağlayarak onları amaca yönlendirmeleridir. İzleyenleri ile olumlu bir iletişim kurmak etkili liderliğin 
olmazsa olmazıdır (Cemaloğlu, 2007, s. 83). Liderliğin en önemli şartlarından biri de örgüt üyelerinin güvenini kazanmaktır (Memişoğlu, 2003, s. 90). Ayrıca, günlük hayatımızda ilişkilerimizi etkileyen iyimserlik ve neşe gibi pozitif duygular olduğu gibi, kızgınlık ve kötümserlik gibi negatif duygular da yaşarı. Bir okulda okul liderinden hem örgüt içerisindeki olumsuz duygularla başa çıkabilmesi hem de özduygularını kontrol etmesi beklenir. Çünkü okul içinde nefret ve kızgınlık gibi duyguların sıklıkla ortaya çıkması örgüt iklimi üzerinde olumsuz etki yapar. Bu durum, çalışanların motivasyonunu ve performansını düşürür (Korkmaz, 2005, s. 404).

Toplumsal ve bireysel önemi çok büyük olduğu kabul gören okullarnn etkililiği ve verimliliğinde liderin rolünün önemli olduğu anlaşılmaktadır (İnandı ve Özkan, 2006, s. 125). Önceki kısımlarda yer verilen literatür temelinde, günümüzün okul liderleri öncelikle çok yönlü olabilmeyi başarmak zorundadırlar (Memişoğlu, 2003, s. 89). Örneğin, veliler artık çocuklarının gideceği okulu seçme, öğrenim gördüğü okulun yönetimine katılma, çocuklarının eğitimine yardımcı olma gibi konularda daha fazla rol üstlenmeye başlamışlardır. Bu anlayış değişikliği geleneksel okul - ev, veli - öğretmen ilisskilerinde de değişiklikler ortaya çıkarmış, geleneksel ilişkilerin yerine daha esnek, katılımcı, karşılıklı etkileşime imkân tanıyan modellerin geliştirilmesini ve uygulanmasını zorunlu kılmışır (Gümüşeli, 2001, s. 536). Bir okul müdürünün kurumun amaçlarını öğretmenlerle paylaşarak bu amaçların gerçekleşmesi için öncü rol oynaması, amaçları günün koşullarına göre öğretmenlerin de görüsslerini alarak yenilemesi, öğretmenler kurulunda amaçları tartışmaya açarak onları amaçlara yönelik olarak teşvik etmesi okulda yönetici liderliğini öne çıkaran davranışlardır (Buluç ve Serin, 2012, s. 452).

Öğretmenlere ve öğrencilere sergiledikleri liderlik rolleri, kişilik özellikleri ve bilgi birikimi ile hem okulda hem de okul dışında okulu temsil konumunda bulunan okul müdürleri bu nitelikleri ile okulun merkezinde yer almaktadırlar. Öğretmenler çalışkan, okula gelen öğrencilerin başarı notu yüksek ve paydaşların okula olan desteği üst düzeyde olsa bile; okul müdürü etkili liderlik davranışları sergileyemez ise, ögrencilerin iyi bir eğitim alması ve topluma faydalı olması noktasında olumsuz etkileri olabilir (Arslanargun, 2011, s. 2648). Yani, ögrencilerin etik ve ahlaki davranışlar ediniminde okul müdürünün etkili liderlik rolü etkili olabilir. Okul müdürlerinin öğretmenleri çalışmalarında teşvik etmesi ve cesaretlendirmesi, öğretmenlerden övgüyle söz etmesi, somut geri bildirimlerde bulunması, okulun diğer paydaşları ile olan işbirliğini ve ilişkilerini güçlendirmesi, okulun hedeflerini veliler ile paylaşması gibi liderlik davranışlarını okulda sergilemeleri beklenir (Beycioğlu, Köybaşı, Uğurlu ve Özer, 2018, s. 25).

Okul müdürünün liderlik davranışları okul iklimini etkiler. Bu iklim doğal olarak öğretmenlere, öğrencilere, okulun diğer çalışanlarına ve ailelere yansır. Okul müdüründen beklenen liderlik davranışlarından birisinin de okulda olumlu bir hava oluşturması olduğu söylenebilir (Şentürk ve Sağnak, 2012, s. 33). Yani, etkili okullarda yöneticiler, örgütün amaçlarının çalısanların tümü tarafindan benimsenmesini sağlayan, öğrenmeyi geliştiren ve etkili öğrenme ortamı yaratan liderlerdir. Bu nedenle okul iklimi, okulda eğitimin kalitesini artıran bir faktör olarak değerlendirilir (Balyer, 2013, s. 183). Eğitim kurumları için en değerli kaynak olan öğretmenlerin doğru yönlendirilmesi ve desteklenmesi bu iklim sayesinde gerçekleşebilir. Bu bağlamda, bir okul müdürü, okulu huzurlu veya huzursuz edebilecek aynı zamanda okulun başarı ya da başarısızlı̆ına doğrudan etki edebilecek önemli faktörlerden birisi olarak değerlendirilmektedir (Avc1, 2015, s. 182).

Okul müdürlerinin liderlik davranışı ile ilgili çalışmalar incelendiğinde; yöneticilerin liderlik davranışlarının öğretmenlerin motivasyonlarını etkilediği (Aksel, 2016, s. 118; Ergen, 2009, s. 110), okulda bürokratik uygulamalar ile okul müdürünün dönüşümcü liderliği arasında bir ilişki olduğu (Buluç, 2010, s. 84), okul müdürlerinin liderlik davranışları ve okul ikliminin ilişkili olduğu (Şentürk ve Sağnak, 2012, s. 40), demokratik liderlik ile öğrenme ikliminin liderlik, değerlendirme, özgürlük, uyum ve işbirliği boyutlar1 arasında ilişki olduğu (Bozdoğan ve Sağnak, 2011, s. 144), liderliğin, bırakınız yapsınlar (laissez-faire) ve istisnalarla yönetim alt boyutları ile örgütsel güven arasında ilişki olduğu (Cemaloğlu ve Kılınç, 2012, s. 148), okul müdürlerinin etik liderliği ile öğretmenlerin iş doyumu ve örgütsel bağlllıkları arasında ilişki olduğu (Madenoğlu, Uysal, Sar1er ve Banoğlu, 2014, s. 61) ve öğretmenlerin örgütsel bağlllık düzeyinin artırlmasında okul yöneticisinin kültürel liderlik rollerinin etkili olduğu (Yörük ve Sağban, 2012, s. 2808) görülmüştür. Literatürden ulaşılan bilgiler bağlamında, okul müdürlerinin liderlik davranışı ile ilişkili olarak öğretmenlerin örgütsel bağlllıkları konusunun önemli olduğu düşünülmüsstür. 


\section{Örgütsel Bağll1ık}

Bağılılık kavramı, tutarlı insan davranışı üreten bir mekanizmanın örtük bir açıklamasını içerir. Bağlılık, bir kişi bir kenar bahsi (side bet) yaparak, tutarlı bir faaliyet alanı ile faaliyet alanı dışındaki çıkarları birbirine bağladığında ortaya çıkar. Kenar bahsi, genellikle kişinin sosyal organizasyonlara katılımının bir sonucudur (Becker, 1960, s. 32). Örgütsel bağlll1k, bir örgütün amaç ve değerlerine, kişinin amaç ve değerlerle ilgili rolüne ve kendi iyiliği için örgütün salt araçsal değerlerini gözetmeksizin örgüte partizanca duygusal bir bağllık olarak tanımlanabilir (Buchanan, 1974, s. 553). Çalışanların genel anlamda örgüte olan bağlllıkları, örgütün tüm etkinliği, çalışanların örgütten ayrılmak istememeleri, çalışanların örgüte karşı olan sadakatleri ve örgütün başarısı için gösterdiği çaba şeklinde tanımlanmaktadır (Bayram, 2005, s. 128). Ayrıca, Özsoy, Ergül ve Bayık (2001, s. 2) örgütsel bağlllı̆̆ı, bireyin üyesi olduğu örgütün çıkarlarını kendi çikarlarını üstünde görmesi olarak tanımlamaktadır. Çöl de (2004, s. 6) örgütsel bağlllık ile ilgili olarak yaptığ1 çalışmalarda örgütsel bağlıllğı, çalışanların örgüt ile kendilerini özdeşleştirmelerinin, örgütün ilkelerini ve hedeflerini özümsemesinin, örgütün başarısı için çabalamasının ve örgütte kalma arzusunun bir ölçüsü olarak ifade etmiştir.

Örgütsel bağll1ık, bireyin kendisini üyesi olduğu örgütle özdeşleştirmesi ve ona katılmassının göreceli gücüdür. Örgütsel bağlllığ değerlendirmede, üç faktör ifade edilmektedir (Akan ve Kilıç, 2019, s. 124): 1) Örgütsel bağlılık örgüt amaçlarının ve değerlerinin özümsenmesi ve bunlara karşı duyulan güçlü inanç, 2) Örgütün başarısı için çaba göstermek, 3) Örgütte kalmak için güçlü bir istek duymak.

Bir okul örgütün amaçlarına ulaşabilmesi için öncelikle yeterliliğinin olması gerekir. Örgüt çalışanlarını örgüt içinde tutma gücü olarak da tanımlanabilen bu yeterliliğin kaynağı ise örgütteki insan faktörüdür. Bu nedenle örgütler varlıklarını sürdürebilmek, hedeflerine ulaşabilmek için, öncelikle çalışanların kişisel beklentilerini karşılayarak, onları örgüt içinde tutmayı başarmalı ve örgütsel bağlılıklarını sağlamalıdırlar (Kurşunoğlu, Bakay ve Tanrıöğen, 2010, s. 102). Örgütsel amaçlara bağlı olan okul örgütü çalışanından, üstlendiği örgütsel rolü başarı ile gerçekleştirirken işgücü kaybının az olmasına katkıda bulunması beklenir. Ayrıca, gönüllü olarak örgütün başarısı ve dolayısıyla örgütsel yaşamın devamı noktasında faaliyetlere katılmaya motive olmakta sorun yaşaması beklenmez (Katz ve Kahn, 1977, s. 436).

Örgütsel bağlllık düzeyi yüksek olan öğretmenlerden bir yandan örgütün geleceğini düşünürken, aynı zamanda örgüte olumlu katkısı olacak yeni görüş ve değişiklikler önererek örgütün gelişmesine katk1 sağlayacak karar ve gelişmelere de destek olması beklenir (Akar, 2014, s. 113). Okula bağlliklların yüksek düzeyde olması sonucunda bu türden öğretmen destekleri, okul başarısını etkilemektedir. Ayrıca, yüksek bağlllık gösteren öğretmenlerin, işe devam isteği, okulunu sahiplenme duygusu, üretme heyecanı gibi motivasyonlarının artması beklenir. Okul müdürlerinin bir lider olarak okul içinde sağlıklı bir iklim oluşturması öğretmenlerin örgütsel bağllikklarının oluşması açısından son derece önemlidir (Akan ve Yalçın, 2015, s. 129).

Öte taraftan, günümüzde okul müdürleri için belki de en zor konu, öğretmenlerin yöneticiye itaat etmesini değil örgüte olan bağllıklarını sağlamaktır. Otoriter yönetim şeklini tercih eden okul müdürleri, bulundukları konumun gücünü kullanarak öğretmenleri itaat etmeye zorlayabilirler, fakat bu itaat öğretmenlerin örgüte bağlanmalarını sağlamaz. Dolayısıyla, bir okul müdürünün öğretmenlerin örgütsel bağlılıklarını oluşturmada, sıradan yöneticilik becerilerinden çok liderlik becerisine sahip olmasının gerekliliği ifade edilebilir (Bektaş, Çoğaltay ve Sökmen, 2014, s. 127). Günümüzde itaat kavramı yerini katılım kavramına bırakmaya başlamıştır. Çalışanlara kendilerini ve kurumu etkileyen konular hakkında ne kadar çok söz hakkı verilir ise, kendilerini işe ve çalıştıkları kuruma o kadar çok adayabilme ihtimalinin yüksek olduğu vurgulanabilir. Bu durum çalıştıkları kuruma olan sadakat ve bağlılıklarını da arttırır. Bu bağlamda, okulda örgütsel bağlllı̆ın oluşturulması veya değiştirilmesi, okul liderlerinin liderlik davranışlarıyla yakından ilişkilidir (Memişoğlu, 2003, s. 91).

Eğitim örgütlerinde temel unsurun insan olması, bağlllı̆̆ın da temelinde örgütü benimseme, örgüt ile kendini özdeşleştirme ve örgütün başarısı için çaba gösterme gibi anlamların olması, örgütün amaçlarına ulaşmasında, eğitim örgütlerinde çalışanların bağlılığının sağlanmasının gerekliliğini ortaya koymaktadır (Buluç ve Serin, 2012, s. 443). Okul müdürlerinden okulun hedeflerine ulaşmasını sağlamak için, öğretmenlerin okula karşı olan bağlllıklarını artırmak, okul ile kendilerini özdeşleştirmelerini sağlamak, onların beklentilerini karşılaması beklenir (Kösterelioğlu ve Olukçu, 2019, s. 33). Okulun amaçlarına ulaşabilmesi için öğretmenlerin kendi istekleri ile okulun amaçları doğrultusunda davranmaları, örgütsel bağlllık için büyük önem taşıdığı anlaşılmaktadır. 
Örgütsel bağllık konusunda dikkate alınması gereken bir diğer husus da verimliliktir. Verimlilik kavramı genel anlamı ile okulun ürettiği hizmete atıfta bulunularak değerlendirilmekte, hizmeti üreten öğretmenlerin insan olmaktan doğan hakları ve moral durumları genellikle bu değerlendirmenin dışında kalmaktadır. Bu bağlamda, çalışanların örgütsel bağlılığını sağlamak için yapılan çalışmalar sadece hizmet üretimini arttırmak amacı ile değil, aynı zamanda yaşamlarının büyük bir kısmını örgüt için harcayan çalışanların değerlerinin ve inançlarının da dikkate alınması önemli görülmektedir (Bayram, 2005, s. 137). Örgüt üyelerinin kurumuna ve işine olan sadakati, işinden aldığı doyum, çalışma hayatında karşılaşılan stres ve tükenmişlikle başa çıkması, öğrenci, veli ve diğer öğretmenler ile olan güçlü ilişkileri, okulların başarıya ulaşmasını sağlayacak ana etkenler olarak ifade edilebilir (Erdem, 2010, s. 520). Literatürden anlaşıldığ1 üzere, bu başarıda örgütsel bağlllğın oldukça önemli olduğu düşünülmektedir.

Okul örgütünde çalışanların sadece örgütte yaşama istekleri yanında çalışanlardan görevlerini en iyi şekilde yapmaları da beklenmektedir. Öğretmenlerden bir kısmı potansiyellerinin en azını ortaya koyarken, bir kısmı ise çıkarları olduğu sürece en üstünü göstermektedirler. Bir kısım çalı̧an ise yapabileceklerinin en üstünü örgütüne ve işine değer verdiği için yapacaktır (Ergün ve Çelik, 2019, s. 115). Bu temelde, örgütün bir parçası olan öğretmenlerin, okulun değerlerine bağlı olması, okulun amaçlarını ve hedeflerini kendi amaçları ve hedefleri olarak görmesi okulun faaliyetlerinin uzun dönemde devam etmesine ve varlığını sürdürmesine büyük katkı sağlayacaktır. Bu nedenle, okul örgütleri örgütsel bağlllıkları yüksek seviyede olan öğretmenlere ihtiyaç duymaktadır (Surat ve Polat, 2020, s. 323).

Okullar hedeflerine ulaşabilmek için öğretmenlere ihtiyaç duymakta, öğretmenler de kendi maddi ve manevi beklentilerini karşılamak üzere okullara katılmaktadırlar. Okul ile çalışan arasında karşılıklı bir alışverişin söz konusu olduğu bu süreçte, çalışan ve okul örgütü arasındaki uyum önem kazanmaktadır (Çetin, Basım ve Aydoğan, 2011, s. 62). Dolayısıyla örgütler bireylerin amaçlarını gerçekleştirme aracı olduğu gibi, bireyler de örgütlerin amaçlarına ulaşma aracı olarak ifade edilebilir. Çalışanların örgüte olan bağlılıklarını artırmak ve örgütte devamlılı̆̆ını sağlamak isteyen örgütlerin çalışanlarına uygun çalışma koşulları yaratması, çalışanların kişisel gelişimlerini desteklemesi, örgüt ve çalışan için ulaşılması mümkün hedefler ortaya koyması, örgüt içi iletişimi sağlıklı hale getirmesi, uygun koşullarda çalışanın kararlara katılımını destekleyerek ve örgüte güveni artırarak çalışanın örgüt içinde kalmaya istekli olmasını sağlamaları gerekmektedir (Yazar ve Özutku, 2019, s. 79). Birey üyesi olduğu örgütten belli ödül ya da çıtı sağlarsa, karşılığında kendini örgüte adamaktadır. Diğer bir ifade ile birey ve örgüt arasındaki ilişkide, birey kendisini örgüte adaması karşılığında belli ödül ya da çıktılar beklemektedir. Örgüte bağlanmanın, çalışanların davranışını etkilemesiyle ilgili dört tür çıktıdan söz edilebilmektedir (Erdoğmuş, 2006, s. 34):

1. Örgütün amaç ve değerlerine tam olarak inananlar, örgütsel etkinliklere aktif olarak katıllılar.

2. Kendilerini örgüte adayan çalışanlar, genel olarak örgütte kalmaya ve örgütün amaçlarına ulaşmasına katkı vermeye güçlü istek duyarlar.

3. Örgüte bağlılık ile işten ayrılma arasında tutarlı ters bir ilişki bulunmaktadır.

4. İşten doyum, işten ayrilmanın başlangıç döneminde önemli kestiricisi iken, zaman geçtikçe bağlllık, işten ayrılmanın doyumdan daha güçlü bir kestiricisi olmaktadır.

Yer verilen literatürden anlaşıldığı gibi örgütsel bağlılık, çalışanların örgüte karşı olan basit bir inanış ve bağıllıklarından fazlasını ifade etmektedir. Yapılan çalışmalarda ortaya konan tanımlamalar ışı̆̆ında örgütsel bağll1ık kavramının tanımını; çalışanların örgütte çalışmayı sürdürme istekleri, örgütün tüm etkinliği, örgütün çıkarlarını ve başarılarını sahiplenme, çalışanın örgüte karşı duyduğu sadakat ve çalıştı̆̆ örgütün başarllı olabilmesi için ortaya koyduğu çaba ve heyecan şeklinde özetlememiz mümkün olabilecektir.

Örgütsel bağlllı̆̆ konusuyla ilgili yürütülen araştırmalar incelendiğinde; öğretmenlerin duygusal ve normatif bağllık biçimlerinin okul kültürünün destek, başarı ve görev boyutları ile pozitif ilişkili olduğu (Sezgin, 2010, s. 155), çalışanların örgüte bağll1ığı ile iş performansı arasında oldukça zayıf bir ilişki olduğu (Mowday, Porter ve Steers, 1982, s. 35), ortaöğretimdeki öğretmenlerin liderlik değişkenleri seti ile örgütsel bağllıkları arasında anlamlı bir ilişki olduğu (Tarter, Hoy ve Bliss, 1989, s. 131), durumsal liderlikte bir müdürün etkinliğinin, eldeki görevle ilgili olarak öğretmenlerin yeterliliklerini, yeteneklerini ve bağllıklarını analiz etme ve buna göre yanıt verme yeteneğiyle ilişkili olduğunu (Kelley, Thornton ve Daugherty, 2005, s. 4), moral, düşünce ve kurumsal bütünlük gibi okul örgütü sağllk faktörlerinin, öğretmenin pozisyonu, medeni durumu ve okuldaki hizmet süresi gibi kişisel özellikleri ile etkileşimler yoluyla öğretmen bağlllı̆̆1 ile ilişkili olduğunu (Tsui ve Cheng, 1999, s. 249), işe geç kalmanın nispeten spontane bir eylem olması ve aynı zamanda bireyin kontrolü dışındaki çok çeşitli faktörlerden etkilenmesi nedeniyle bağllık ve gecikme 
arasında negatif ilişki olduğu (Mathieu ve Zajac, 1990, s. 184), yöneticilerin etik liderlik davranışlarının, okullardaki örgütsel adalet davranışlarını biçimleyerek öğretmenlerin okullarına bağlılık oluşturduğu (Uğurlu ve Üstüner, 2011, s. 444), okullardaki akademik iyimserlik ile öğretmenlerin örgütsel bağlllıklar1 arasında pozitif yönde bir korelasyon olduğu (Çoban ve Demirtaş, 2011, s. 345), öğretim liderliği ile örgütsel bağlılık arasında anlamlı bir ilişkinin olduğu (Buluç ve Serin, 2012, s. 454), öğretmenlerin örgütsel bağlllığ1 ile örgütteki sinizm ve örgütsel muhalefet arasında bir ilişki olduğu (Yıldız, 2013, s.871), öğretmenlerin örgütsel bağlılıkları ile motivasyon arasında anlamlı ilişki bulunduğu (Bang, Rose ve Reio, 2013, s. 96; Kalay, 2015, s. 122), toksik liderlik ile örgütsel bağl1lık arasında negatif ilisski olduğu (Bozkurt, Çoban ve Çolakoğlu, 2020, s. 713) ve insan kaynakları yönetimi uygulamalarının çalısanların örgütsel bağlllığ1 üzerinde etkili olduğu (Karaca, Bayram ve Harmanc1, 2020, s. 206) görülmektedir. Literatürde mevcut araştırmaların bir doğurgusu olarak, okul müdürlerinin liderlik davranışları ile öğretmenlerin örgütsel bağgllıkları arasındaki ilişkinin çalşsıldığı bir araştırmaya ihtiyaç durumu tespit edilmiştir. $\mathrm{Bu}$ çalışma bu motivasyonla gerçekleştirilmiştir.

\section{Yöntem}

\section{Araştırmanın Modeli}

Bu araştırma, ilişkisel tarama modeline (Büyüköztürk, Kılıç-Çakmak, Akgün, Karadeniz ve Demirel, 2012, s. 23) dayanan betimsel bir çalışmadır. Araştırmada ortaokul kademesinde çalışan öğretmenlerin okul müdürlerinin liderlik becerilerine yönelik görüşleri ile öğretmenlerin örgütsel bağlllıkları arasındaki ilişki incelenmiştir.

\section{Kat1lımcilar}

Bu araştırmanın çalışma grubunu 2020-2021 Eğitim-Öğretim yllında Zonguldak ili Ereğli ilçesinde kamu okullarında çalışan 274 öğretmen oluşturmaktadır. Araştırmaya katılan öğretmenlere ait demografik özellikler Tablo 1'de sunulmuştur. Tablo 1 incelendiğinde araştırmanın katılımcılarının \%65.3'ünün kadın (179), \%34.7’sinin ise erkek (95) olduğu görülmektedir.

Tablo 1. Katillmolarn Demografike Bilgileri $(n=274)$

\begin{tabular}{|c|c|c|c|}
\hline Değişken & Düzey & $\mathbf{N}$ & $\%$ \\
\hline \multirow{2}{*}{ Cinsiyet } & Kadın & 179 & 65.3 \\
\hline & Erkek & 95 & 34.7 \\
\hline \multirow{5}{*}{ Mesleki Kıdem } & $1-5 \mathrm{yll}$ & 31 & 11.3 \\
\hline & $6-10 \mathrm{yll}$ & 49 & 17.9 \\
\hline & $11-15$ y1l & 57 & 20.8 \\
\hline & $16-20 \mathrm{yil}$ & 59 & 21.5 \\
\hline & 21 ve üstü & 78 & 28.8 \\
\hline \multirow{5}{*}{$\begin{array}{l}\text { Okulunuzdaki Öğretmen } \\
\text { Sayıs1 }\end{array}$} & $0-10$ & 17 & 6.2 \\
\hline & $11-20$ & 35 & 12.8 \\
\hline & $21-30$ & 58 & 21.2 \\
\hline & $31-40$ & 44 & 16.1 \\
\hline & 41 ve üstü & 120 & 43.8 \\
\hline \multirow{3}{*}{ Öğrenim Durumunuz } & Ön Lisans & 5 & 1.8 \\
\hline & Lisans & 226 & 82.5 \\
\hline & Lisans Üstü & 43 & 15.7 \\
\hline \multirow{5}{*}{$\begin{array}{l}\text { Kaç Yıldır Bu Okulda } \\
\text { Ögretmensiniz }\end{array}$} & $1-5 \mathrm{yll}$ & 140 & 51.1 \\
\hline & $6-10 \mathrm{yll}$ & 74 & 27 \\
\hline & $11-15 \mathrm{yll}$ & 30 & 10.9 \\
\hline & $16-20 \mathrm{yll}$ & 20 & 7.3 \\
\hline & 21 ve üstü & 10 & 3.6 \\
\hline \multirow{3}{*}{ Mezun Olduğunuz Fakülte } & Eğitim F. & 178 & 65 \\
\hline & Fen-Edebiyat F. & 69 & 25.1 \\
\hline & Diğer & 27 & 9.9 \\
\hline
\end{tabular}

Tablo 1 incelendiğinde; katıllımcıların \%11.3’ünün mesleki kıdemi 1-5 yıl, \%17.9'unun 6-10 yll, $\% 20.8^{\prime}$ inin 11-15 yll, \%21.5'inin 16-20 y1l ve \%28.5' inin 21 yll ve üstü olduğu görülmektedir. Katıtlımcıların \%6.2'si 10 ve aşağı öğretmen sayısına sahip okullarda, \%12.8'i 11 ile 20 arası öğretmen sayısına sahip okullarda, \%21.2'si 21 ile 30 arası öğretmen sayısına sahip okullarda, \%16.1'i 31 ile 40 aras1 ögretmen sayısına sahip okullarda, \%43.8’i 41 ve daha fazla öğretmen sayısına sahip okullarda çalışmaktadır. Katılımcıların \%1.8'i ön lisans, \%82.5'i lisans ve \%15.7’si lisansüstü eğitime sahiptir. Katılımcıların \%51.1'i 1 ile 5 yil arasında okullarında çalışmakta, \%27’si 6 ile 10 yil arasında okullarında 
çalışmakta, \%10.9’u 11 ile 15 yıl arasında okullarında çalışmakta, \%7.3’ü 16 ile 20 yll arasında okullarında çalışmakta, \%3.6'sı ise 21 yıldan fazla süredir okullarında çalışmaktadır. Katılımcılardan Eğitim Fakültesi mezunu olanların oranı \%65, Fen-Edebiyat Fakültesi mezunlarının oranı \%25.1, diğer fakültelerden mezunların oranı ise $\% 9.9$ 'dur.

\section{Veri Toplama Araçları}

Araştırmanın verileri “Okul Liderliği Ölçeği” ve "Örgütsel Bağlllık Ölçeği” ile elde edilmiştir. Ölçekleri geliştiren ve uyarlayan araştırmacılardan gerekli ölçek kullanım izinleri alınmıştır.

Okul Liderliği Ölçğgi. Beycioğlu vd. (2018) tarafindan geliştirilen bir ölçektir. Toplamda 31 maddeden oluşan ölçek 5'li Likert tipindedir (1: kesinlikle katılmıyorum, 2: katılmıorum, 3: kısmen katıllyorum, 4: katıllyorum, 5: kesinlikle katıllıorum). Ölçeğin ilk oniki maddesi "destek" boyutunu, ikinci onbeş maddesi "işbirliği" boyutunu ve son dört maddesi "açıklık" boyutunu oluşturmaktadır. Bu çalışmada ölçeğin Cronbach alfa katsayısı $(\alpha)$; ölçeğin tamamı için 0.97 olarak hesaplanmıştır.

Örgütsel Bağhllk Ölçeğ̈. Ergün ve Çelik (2019) tarafindan geliştirilen bir ölçektir. Toplamda 15 maddeden oluşan 5'li Likert ölçek tipindedir (1: hiç katılmıyorum, 2: az katıllyorum, 3: orta düzeyde katıllyorum, 4: büyük oranda katıllyorum, 5: tamamen katıllyorum). Ölçek, "zoraki bağll1ık", "çıarc1 bağlllık" ve "ahlaki bağlllık" olmak üzere, herbirisi beşer madde içeren toplamda üç boyuttan oluşmaktadır. Bu çalışmada ölçeğin Cronbach alfa katsayısı $(\alpha)$; ölçeğin tamamı için 0.70 olarak hesaplanmıştır.

\section{Verilerin Analizi}

Verilerin analizi SPSS programı ile yapılmıştır. Araştırmada kullanılan veri toplama araçlarının ilk bölümünü oluşturan demografik göstergelere ait verilerin sıklığ1 ve yüzdeleri belirlenmiştir. Okul müdürlerinin liderlik davranışına yönelik öğretmen algıları ile öğretmenlerin örgütsel bağlllık düzeylerinin belirlenmesinde de yine betimsel istatistiklerden yararlanılmıştır. Kullanılan ölçeklere uygulanan Kolmogorov-Smirnov testi sonucunda her iki ölçek maddelerine verilen yanıtların normal dağılım göstermediği belirlenmiştir. Bu nedenle okul müdürlerinin liderliklerine yönelik öğretmen algılarının ve öğretmenlerin örgütsel bağlılık düzeylerinin cinsiyet bakımından istatistiki açıdan farkllık gösterme durumunun incelenmesi amacıyla Mann Whitney U-testi ve okul müdürlerinin liderliklerine yönelik öğretmen algılarının ve öğretmenlerin örgütsel bağlllık düzeylerinin mesleki kıdem bakımından istatistiki açıdan farklılık gösterme durumunun incelenmesi amacıyla Kruskal-Wallis testi yapılmıştır. Okul müdürlerinin liderliği ile öğretmenlerin örgütsel bağlllıkları arasındaki ilişkinin incelenmesi amacıyla Pearson korelasyon testi yapılmıştır. Okul müdürlerinin liderlik davranışının öğretmenlerin örgütsel bağlllı̆ıııı yordamasını göstermek amacıyla regresyon testi yapılmıştır.

\section{Bulgular}

\section{Öğretmenlerin görüşlerine göre; okul müdürlerinin sergilediği liderlik davranışları ve öğretmenlerin örgütsel bağlılık düzeyleri nasıldır?}

$\mathrm{Bu}$ alt probleme ilişkin veriler analiz edilirken verilerin aritmetik ortalamalarına ve standart sapmaya bakılmıştır. Elde edilen bulgular Tablo 2'de sunulmuştur.

Tablo 2. Ögrretmenlerin Görüşlerine Göre; Okul Müdürlerinin Sergilediğg Liderlik. Davranışlar ve Öğretmenlerin Örgütsel Bağhllk. Düzeylerine Yönelik Ortalamalar (X) ve Standart Sapma Değerleri (S) (n=274)

\begin{tabular}{lccccc}
\hline & $\boldsymbol{n}$ & $\boldsymbol{M i n}$ & $\boldsymbol{M a x}$. & $\boldsymbol{X}$ & $\boldsymbol{s}$ \\
\hline Okul Müdürlerinin Liderliği & 274 & 1.00 & 5.00 & 3.79 & .678 \\
Örgütsel Bağlllık & 274 & 2.00 & 5.00 & 3.77 & .439 \\
\hline
\end{tabular}

Tablo 2 incelendiğinde ögretmenlerin okul müdürlerinin liderliklerine yönelik algılarının "Katıllyorum" ( $\bar{x}=3.79)$ ve örgütsel bağlllıklarının "Katılıyorum" ( $\bar{x}=3.77)$ düzeylerinde gerçekleştiği görülmüş̧ür. Buna göre öğretmenlerin okul müdürlerinin liderliğine yönelik algılarının ve örgütsel bağlllık düzeylerinin ortanın üstünde olduğu söylenebilir.

\section{Okul müdürlerinin sergilediği liderlik davranışlarına yönelik öğretmenlerin görüşleri, öğretmenlerin cinsiyetlerine göre istatistiki açıdan anlamlı farklılık göstermekte midir?}

$\mathrm{Bu}$ alt probleme ilişkin veriler analiz edilirken Mann Whitney $\mathrm{U}$ Testi analizi kullanılmışıtır. Elde edilen bulgular Tablo 3’te sunulmuştur. 
Tablo 3. Okul Müdürlerinin Sergilediŭi Liderlik Davranışlarna Yönelik Öğretmen Görüslerinin Öğretmenlerin Cinsiyetlerine Göre Mann Whitney U Testi Sonuçlar $(n=274)$

\begin{tabular}{ccccc}
\hline & Cinsiyet & N & Mean Rank & Sum of Ranks \\
\hline \multirow{2}{*}{ Okul Müdürünün Liderliği } & Kadın & 179 & 128.00 & 22912.50 \\
& Erkek & 95 & 155.39 & 14762.50 \\
\hline
\end{tabular}

Analiz sonucunda, cinsiyet değişkenine göre, öğretmenlerin okul müdürlerinin liderliklerine yönelik görüşleri arasında erkek öğretmenler lehine anlamlı bir fark olduğu görülmüştür.

Okul müdürlerinin sergilediği liderlik davranışlarına yönelik öğretmenlerin görüşleri, mesleki kıdemlerine göre istatistiki açıdan anlamlı farklılık göstermekte midir?

$\mathrm{Bu}$ alt probleme ilişkin veriler analiz edilirken Kruskal-Wallis Testi analizi kullanılmıştır. Elde edilen bulgular Tablo 4'te sunulmuştur.

Tablo 4. Okul Müdürlerinin Sergilediği Liderlik Davranıslarna Yönelik Öğretmen Görüslerinin Ögrretmenlerin Mesleki Kidemlerine Göre Kruskal-Wallis Testi Sonuçlar $(n=274)$

\begin{tabular}{lccc}
\hline & Öğretmenlikteki kıdeminiz & $\boldsymbol{n}$ & Mean Rank \\
\hline & $1-5$ & 31 & 139.39 \\
Okul Müdürlerinin Liderliği & $6-10$ & 49 & 153.22 \\
& $11-15$ & 57 & 131.09 \\
& $16-20$ & 59 & 133.48 \\
& $21+$ & 78 & 134.60 \\
\hline
\end{tabular}

Okul müdürlerinin liderliklerine yönelik öğretmenlerin görüşleri arasında mesleki kıdemlerine göre istatistiki açıdan anlamlı farklılık ortaya çıkmamıştır.

Öğretmenlerin örgütsel bağlılı̆̆ına yönelik öz görüşleri, cinsiyetlerine göre istatistiki açıdan anlamlı farklılık göstermekte midir?

$\mathrm{Bu}$ alt probleme ilişkin veriler analiz edilirken Mann Whitney U Testi analizi kullanılmıştır. Elde edilen bulgular Tablo 5’te sunulmuştur.

Tablo 5. Öğretmenlerin Örgütsel Băghliğna Yönelik Öz. Görüslerinin Öğretmenlerin Cinsiyetlerine Göre Mann Whitney U Testi Sonuclar $(n=274)$

\begin{tabular}{lcccc}
\hline & Cinsiyetiniz & $\boldsymbol{n}$ & Mean Rank & Sum of Ranks \\
\hline \multirow{2}{*}{ Örgütsel Bağl1lık } & Kadın & 179 & 133.95 & 23977.50 \\
& Erkek & 95 & 144.18 & 13697.50 \\
\hline
\end{tabular}

Cinsiyet değişkenine göre, öğretmenlerin örgütsel bağlllık düzeyleri arasında anlamlı bir fark olmadığ1 görülmüştür.

Öğretmenlerin örgütsel bağlılı̆̆ına yönelik öz görüşleri, mesleki kıdemlerine göre istatistiki açıdan anlamlı farklılık göstermekte midir?

$\mathrm{Bu}$ alt probleme ilişkin veriler analiz edilirken Kruskal-Wallis Testi analizi kullanılmıştır. Elde edilen bulgular Tablo 6'da sunulmuştur.

Tablo 6. Öğretmenlerin Örgütsel Bağlllı̆gna Yönelik Öz. Görüslerinin Öğretmenlerin Mesleki Kıdemlerine Göre KruskalWallis Testi Sonucları $(n=274)$

\begin{tabular}{lccc}
\hline & Öğretmenlikteki k1deminiz & $\boldsymbol{N}$ & Mean Rank \\
\hline & $1-5$ & 31 & 152.53 \\
Örgütsel Bağllikk & $6-10$ & 49 & 137.07 \\
& $11-15$ & 57 & 135.14 \\
& $16-20$ & 59 & 146.86 \\
& $21+$ & 78 & 126.44 \\
\hline
\end{tabular}

Öğretmenlerin örgütsel bağl1lık düzeyleri arasında mesleki kıdemlerine göre istatistiki açıdan anlamlı farklılık ortaya çıkmamıştır. 
Öğretmen görüşlerine göre okul müdürlerinin sergilediği liderlik davranışı ile öğretmenlerin örgütsel bağlılığına ilişkin öğretmen görüşleri arasında ilişki var mıdır?

$\mathrm{Bu}$ alt probleme ilişkin veriler analiz edilirken Korelasyon testi analizi kullanılmıştır. Elde edilen bulgular Tablo 7'de sunulmuştur.

Tablo 7. Ögrretmen Görüslerine Göre Okul Müdürlerinin Sergilediği Liderlik Davramısı ile Ögrretmenlerin Örgütsel Bağhlihğ Arasindaki Illiski (Korelasyon Testi)

\begin{tabular}{lcc}
\hline Değgigkenler & 1 & 2 \\
\hline 1- Okul Müdürlerinin Liderliği & 1 & \\
2- Örgütsel Bağlllk & $.406^{* *}$ & 1 \\
\hline
\end{tabular}

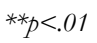

Okul müdürlerinin liderlik davranışları ile örgütsel bağlllık ölçeği arasında $(r=.406 ; p<.05)$ pozitif yönde ve orta düzeyde bir ilişki olduğu görülmüştür.

\section{Okul müdürlerinin liderlik davranışı öğretmenlerin örgütsel bağlılı̆ını yordamakta mıdır?}

$\mathrm{Bu}$ alt probleme ilişkin veriler analiz edilirken Regresyon testi analizi kullanılmışıtır. Elde edilen bulgular Tablo 8'de sunulmuştur.

Tablo 8. Okul Müdürlerinin Liderlik Davranısınnn Öğretmenlerin Örgütsel Bağhllkelar Üzerindeki Etkisi (Regresyon Testi)

\begin{tabular}{|c|c|c|c|c|c|}
\hline Bağımlı & Bağımsız & B & $\mathbf{t}$ & $\mathrm{p}$ & $\mathbf{R}^{2}$ \\
\hline Örgütsel Bağlilık & Okul Müdürlerinin Liderliği & 0.406 & 7.32 & 0 & 0.16 \\
\hline
\end{tabular}

$F=53.64 ; p<0.01$

Anlamlı bir regresyon modeli $\mathrm{F}(1.27)=53.64, \mathrm{p}<0.01$ ve bağımlı değişkendeki varyansın \%16.5’unu $\left(\mathrm{R}^{2}{ }_{\text {Square }}=.165\right)$ bağımsız değişken tarafindan açıklandığı bulunmuştur. Buna göre bağımsız değişken okul müdürlerinin liderlik davranışları bağımlı değişken olan öğretmenlerin örgütsel bağlılığını olumlu ve anlamlı olarak yordamaktadır $(\beta=.406, \mathrm{t}(272)=7.32$. $\mathrm{p}<0.01)$.

\section{Tartışma, Sonuç ve Öneriler}

Bu çalısmada, öğretmenlerin görüşlerine göre; okul müdürlerinin liderlik davranışları ile örgütsel bağlllık düzeyleri arasındaki ilișki incelenmiștir. Araștırmanın birinci alt probleminde, öğretmenlerin okul müdürlerinin liderlik davranışlarına yönelik görüssleri ve örgütsel bağlllık düzeylerinin, orta üstü düzeyde olduğu tespit edilmiştir ve olumlu olarak değerlendirilebilir. Bu çalışmadaki öğretmenlerin okul müdürlerinin liderliklerine yönelik görüş düzeyi sonuçlarına benzer olarak, Avc1 (2015, s. 180), okul müdürlerinin liderlik stillerine ilişkin görüşlerini "katılıyorum" olarak tespit etmiştir. Cemaloğlu ve Kılınç (2012, s. 148), okul müdürlerinin dönüşümcü liderlik davranışlarını işlemci liderlik davranışlarına göre daha fazla gösterdiklerini ve liderlik stilleri ortalama görüşlerinin "kararsızım" düzeyinde olduğu ortaya koymuştur ve bu çalışmadaki sonuç ile örtüşmemektedir. Bu çalışmadaki öğretmenlerin örgütsel bağlllık düzeyi sonuçlarına benzer olarak, Leblebici (2016, s. 72), öğretmenlerin özdeşleşme düzeylerine ilişkin görüsslerini "katıllyorum" olarak tespit etmiştir. Ayrıca, Kurşunoğlu vd. (2010, s. 105) ile Akan ve Yalçın (2015, s. 143), öğretmenlerin örgütsel bağllliklarının "katıllyorum" düzeyinde olduğunu tespit etmiştir. Öte taraftan, Gören ve Sarpkaya’nın (2014, s. 75) örgütsel bağlllık düzeyine ilişkin elde ettikleri “az katıliyorum" görüşü ile bu çalışmadaki sonuç örtüşmemektedir.

Araştırmanın ikinci alt probleminde okul müdürlerinin liderliklerine yönelik öğretmen görüşlerinin cinsiyet değişkenine göre farklılık gösterip göstermediği incelenmiştir. Cinsiyet değişkenine göre, öğretmenlerin okul müdürlerinin liderlik davranışlarına yönelik görüşleri arasında erkek öğretmenler lehine anlamlı bir fark olduğu görülmüștür. Buna göre, erkek öğretmenlerin okul müdürlerinin liderlik davranışlarına yönelik görüşlerinin kadınlara göre daha yüksek olduğu görülmektedir. Kulu (2020, s. 77), çalışmasında erkek öğretmenlerin okul müdürlerinin liderlik davranışlarına yönelik görüşlerinin kadınlara göre daha yüksek olduğu sonucuna ulaşmıştır. Diğer benzer bir çalışmada ise öğretmenlerin, okul müdürlerinin dönüşümcü liderlik ve işlemci liderlik özelliklerine ilişkin görüşleri cinsiyetlerine göre farklılaşmamaktadır (Avc1, 2015, s. 180). 
Araştırmanın üçüncü alt probleminde öğretmenlerin okul müdürlerinin liderlik davranışlarına yönelik görüşlerinin mesleki kıdem değişkenine göre farklılık gösterip göstermediği incelenmiştir. 6-10 yıl mesleki kıdeme sahip öğretmenler diğer öğretmenlere göre okul müdürlerinin liderlik rollerini daha fazla yerine getirdiklerini düşünmektedirler. Bunun nedeni 6-10 y1llık mesleki deneyime sahip öğretmenlerin meslekte yeni olmalarına rağmen edindikleri deneyimi bilgi ve yeterlikleriyle ve dolayısıyla müdürlerin rolüyle birleştirmeleri olabilir. Okul müdürlerinin liderlik davranışlarına yönelik öğretmenlerin görüşleri mesleki kıdemlerine göre istatistiki açıdan anlamlı farklılık ortaya çıkarmamaktadır. Tahaoğlu ve Gedikoğlu (2009, s. 290), gerçekleştirdikleri çalşmada ilköğretim okulu öğretmenlerinin okul müdürlerinin liderlik rollerine ilişkin görüşleri mesleki kıdeme göre anlamlı bir farklılık göstermediği sonucuna ulaşmışlardır.

Araştırmanın dördüncü alt probleminde öğretmenlerin örgütsel bağlllık düzeylerinin cinsiyetlerine göre istatistiki açıdan anlamlı farkllılı gösterip göstermediği incelenmiştir. Erkek öğretmenler kadın ögretmenlere göre daha yüksek düzeyde örgütsel bağlllık göstermelerine rağmen, cinsiyet değişkenine göre, öğretmenlerin örgütsel bağlllık düzeyleri arasında anlamlı bir fark olmadığı görülmüştür. Başka araştırmalarda da öğretmenlerin cinsiyet değişkenine göre örgütsel bağlllık algisı açısından anlamlı bir fark olmadığ1 ortaya konulmuştur (Demirtaş, 2010, s. 190; Nartgün ve Menep, 2010, s. 300). Ayrıca, Kurşunoğlu vd. (2010, s. 106) tarafindan yapilan başka bir araştırmada ise örgütsel bağlılığın alt boyutları olan duygusal ve devam bağlılığı puanlarının cinsiyet değişkenine göre anlamlı bir farklılık göstermediği görülmüsstür. Öte taraftan, Akan ve Kılıç (2019, s. 128), erkek öğretmenlerin kadın öğretmenlere göre anlamlı bir biçimde örgütsel bağlılıklarının daha fazla olduğunu ortaya koymuşlardır.

Araştırmanın beşinci alt probleminde öğretmenlerin örgütsel bağlllık düzeylerinin mesleki kıdemlerine göre istatistiki açıdan anlamlı farklılık gösterip göstermediği incelenmiştir. 1-5 yıl mesleki kıdeme sahip ögretmenler diğer öğretmenlere göre daha yüksek düzeyde örgütsel bağlllı göstermelerine rağmen, öğretmenlerin örgütsel bağll1ık düzeyleri mesleki kıdemlerine göre istatistiki açıdan anlamlı bir farklılık ortaya çıkarmamıştır. Benzer biçimde, Ay ve Koç (2014, s. 76), öğretmenlerin örgütsel bağlllıklarının çalışma süreleri açısından farklılaşma göstermediğini ortaya koymuşlardır. Karataş ve Güleş (2010, s. 83), ögrretmenlerin örgütsel bağlılıklarının mesleki kıdem açısından farklılaşmadığını tespit etmiştir. Erdaş (2009, s. 88) çalışmasında farklı mesleki kıdeme sahip öğretmenlerin örgütsel bağllık düzeylerinin aynı seviyede olduğunu tespit etmiştir.

Araştırmanın altıncı alt probleminde okul müdürlerinin sergilediği liderlik davranışı ile öğretmenlerin örgütsel bağlllığı arasındaki ilişki incelenmiştir. Okul müdürlerinin liderlik davranışı ile öğretmenlerin örgütsel bağlllık düzeyleri arasında pozitif yönde ve orta düzeyde bir ilişki olduğu görülmüştür. Kilınçarslan'ın (2013, s. 84) çalışması da bu sonucu desteklemektedir. Bu durum, öğretmenlerin okul müdürlerinin liderlik rolleri düzeyine ilişkin hissettikleri olumlu görüşlerin öğretmenlerin örgütsel bağlllık düzeylerini olumlu yönde etkileyebileceği şeklinde yorumlanabilir. Erdoğdu ve Aydındağ (2013, s. 168) öğretmenlerin örgütsel bağlllıklarının algılanan yönetici davranışları açısından incelemesini gerçekleştirdikleri araştırmada, genel olarak okul müdürlerinin gösterdikleri olumlu davranışların bağlllığ1 artırdığını tespit etmiş̧ir. Yapılan bir başka çalışmada ise okul müdürlerinin öğretimsel liderlik rolleri ile ögretmen bağlllığı düzeyleri arasında pozitif ve orta düzeyde anlamlı bir ilişki bulunmuştur (Kösterelioğlu ve Olukçu, 2019, s. 39). Dönüşümcü liderlik stili ile örgütsel bağllık arasında pozitif yönde anlamlı bir ilişski tespit edilmiştir (Akan ve Yalçın, 2015, s. 139). Sonuç olarak, literatürdeki çalışmalara ve bu araştırmanın sonuçlarına göre okul müdürlerinin liderlik davranışları ile öğretmenlerin örgütsel bağlılık düzeyleri arasında anlamlı bir ilişki olduğu ortaya konulmuştur. Okul müdürlerinin uygulamada gösterdikleri liderlik yöntemleri ile öğretmenlerin okula olan bağlllı̆ı arasında yüksek pozitif bir ilişki olduğunu göstermektedir. Bu sonuç, örgüt üyelerinin sadakat göstererek örgütün başarısı için çaba gösterme arzusu ve örgütün bir üyesi olmaktan duydukları heyecan ile ilgili olan örgütsel bağlllık algisının yöneticinin yönetsel davranışlarından etkilendiği düşüncesi ile (Bektaş vd., 2014, s. 127) örtüşmektedir. Terzi ve Kurt (2005, s. 109) gerçekleştirdikleri çalısmada demokratik yönetici davranışlarının öğretmenlerin örgütsel bağlıllğını arttırırken, emredici ve ilgisiz yönetici davranışları ile öğretmenlerin örgütsel bağglllğı arasında olumsuz bir ilişki olduğu sonucuna ulaşmışlardır. Yöneticilerin örgüt çalışanlarının örgüte bağlanmalarını sağlamak belki de en çok zorlandıkları alandır. Çünkü örgüte inanmak, sadakat göstermek, örgütte çalş̧maya devam etme isteği ve örgütte bulunmaktan duyulan gurur itaat veya emir ile değil gönüllülük ile gerçekleşir. Dolayısıyla bir yöneticinin sıradan yöneticilik becerilerinden daha çok liderlik becerilerine sahip olmasının gerekliliği ifade edilebilir.

Araştırmanın yedinci alt probleminde okul müdürlerinin liderlik davranışlarının öğretmenlerin örgütsel bağl1lıkları üzerindeki etki düzeylerinin yordanma durumları tespit edilmiştir. Okul müdürlerinin 
liderlik davranışı öğretmenlerin örgütsel bağlılığını olumlu ve anlamlı olarak yordamaktadır. Bu sonuç, Okçu'nun (2014, s. 516) bulduğu sonuç ile örtüşmektedir. Terzi ve Kurt (2005, s. 109) öğretmenlerin çalıştıkları okullardaki yöneticileri büyük bir çoğunlukla demokrat olarak nitelendirdiklerini ve demokratik yönetici davranışlarının öğretmenlerin okullarına olan bağlılıklarını arttırdığını ortaya koymuşlardır. Özbek (2011, s. 241), çalışanların çalışma ortamı içinde algıladıkları güven arttıkça bağlılıklarının da arttığını bulmuştur. Okul müdürlerinin liderlik stilinin öğretmenlerin örgütsel bağll1ıklarının anlamlı bir yordayıcısı olduğu tespit edilmiştir (Akan ve Yalçın, 2015, s. 143).

Eğitim sistemimiz açısından bakıldığında yönetmeliklerde okul müdürü eğitim-öğretim sürecinin yönetiminde birinci derece sorumlu lider olarak ifade edilmektedir. Bu bağlamda, okul müdürlerinin uygulamalarını sadece yönetmelikleri dikkate alarak yürütmeleri yerine değişimi anlayacak, yürütecek, problem çözme becerilerine sahip, bilgiyi kullanabilen liderler olmaları gerekmektedir (Balyer, 2013, s. 203). Bu sonuçlar temelinde, okul çalışanlarına karşı saygılı ve eşit olan, makamının gücünü kişisel çıkarları için değil, kurumun çıarları için kullanan lider yöneticiler okulu amaçlarına ulaştırmada en önemli faktör olan öğretmenlerin okula olan bağlllıklarını da arttıracağı vurgulanabilir. Okul müdürlerinin liderlik rollerini sergilediklerinde, geleneksel hiyerarşik bir yönetim anlayışı yerine işbirliği içinde çalışan bir yapıda oldukça ögretmenlerin örgütsel bağlllık düzeylerini yükseltebilecekleri söylenebilir. Ayrıca, okul müdürlerinin eğitim-öğretim faaliyetlerinde aksamaya neden olabilecek faktörleri ortadan kaldırarak kurum içinde disiplin ve düzen oluşturmayı başardıklarında, çalışanların fikirlerine önem verdiklerinde ve kendilerini duyulan güveni boşa çıkarmadıklarında, öğretmenlerin örgütsel bağll1ık düzeylerini yükseltebilecekleri söylenebilir.

Liderler okullarını amaçlara yönelik harekete geçirebilirler. Dolayısıyla lider yöneticilerin yetiştirilmesi ve iş başına getirilmesi önem kazanmaktadır. Duruma hem yeni liderleri yetiştirmek, hem de mevcutları geliştirmek üzere iki yönlü olarak bakılmalıdır (Memişoğlu, 2003, s. 89).

Araştırmada ortaya çıkan sonuçlardan hareketle okul müdürlerinin etkili liderlik davranışları göstermesinin, öğretmenlerin okullarına olan bağlllıklarının artırılmasında etkili bir faktör olduğu, bu bağlamda okul müdürlerine etkili liderlik davranışları ve bunların okullarda nasıl uygulanabileceği konusunda hizmet içi eğitimler düzenlenmesi gerektiği söylenebilir.

Örgütsel bağlllık kavramının okulların işleyişi ve öğretmenlerin gösterecekleri performansları açısından önemli kavramlardan biri olduğu anlaşılmaktadır. Araştırma sonuçları dikkate alınarak okul müdürlerinin okul başarısında bu derece önemli görülen öğretmenlerin örgütsel bağlllıklarını artırmak için öğretmenlerin çalışmalarını yazılı ya da sözlü olarak takdir etme ve yeri geldiğinde ödüllendirme gibi iş doyumunu arttırıcı davranışlar göstermeleri, önerilebilir. Öğretmenlerin kendilerini bir alenin üyesi olarak hissetmelerini sağlamaları, etkili ve başarılı okul oluşturma amacına ulaşmada kolaylık sağlayabilir.

Okul müdürleri, okulla ilgili kararlar alırken tüm öğretmenlerin görüşlerini dikkate almaları ve öğretmenlerin mesleki açıdan kendilerini yetiştirme ve geliştirmeleri için hizmet içi eğitim çalışmalarına teşvik etmeleri hem öğretmenlerin hem de öğrencilerin kaynaşmasını sağlamak için çeşitli sosyal faaliyetler gerçekleştirilmesine öncülük etme gibi davranışlar sergilemesi örgütsel bağllliğ1 arttırabilir.

Bu çalışma veriye dayalı kanıtlar sunma noktasında güçlü iken 2020-2021 eğitim-öğretim yılında Zonguldak ili Ereğli ilçesinde kamu okullarında çalışan 274 öğretmenin verileri ve verilerin toplandığı tarihteki görüşleri ve durumlarıyla sınırlıdır. Ayrıca, kullanılan istatistik program, analiz edilen tekniklerdeki algoritmalar ve kullanılan ölçekler diğer sınırlılıkları oluşturmaktadır.

\section{Etik Beyan}

"Ortaokul Ögrretmenlerine Göre Okul Müdürlerinin Liderlik Davramsşlarn ile Ögrretmenlerin Örgütsel Bağhlĭgınn Incelenmesi" başlıklı çalışmanın yazım sürecinde bilimsel kurallara, etik ve alıntı kurallarına uyulmuş; toplanan veriler üzerinde herhangi bir tahrifat yapılmamış ve bu çalışma herhangi başka bir akademik yayın ortamına değerlendirme için gönderilmemiştir. Ayrıca Zonguldak Bülent Ecevit Üniversitesi İnsan Araştırmaları Etik Kurulu'ndan 26.10.2020 tarih ve 892 karar saylı etik kurulu izni alınmıştır.

\section{Kaynakça}

Akan, D. ve Kilıç, M. E. (2019). Öğretmenlerin örgütsel bağlllık düzeyleri ile okul etkililiği arasındaki ilişkinin incelenmesi. Ekev Akademi Dergisi, 80, 123-136. 
Akan, D. ve Yalçın, S. (2015). Okul yöneticilerinin liderlik stilleri ile öğretmenlerin örgütsel bağl1lıkları arasındaki ilişkinin incelenmesi. Ë̆itim ve Insani Bilimler Dergisi: Teori ve Uygulama, 6(11), 123-150.

Akar, H. (2014). Okul yöneticilerinin örgütsel bağllliklarının incelenmesi. Kilis 7 Arahk Üniversitesi Sosyal Bilimler Dergisi, 4(8), 110-132.

Akcakoce, A. ve Bilgin, K. U. (2016). Okul müdürlerinin liderlik davranışı ve öğretmen performansı. Cağdaş Yönetim Bilimleri Dergisi, 2(2), 1-23.

Aksel, N. (2016). Ortaokul müdürlerinin dönüsümcü liderlik davranıslarn ile ögretmenlerin motivasyonu arasindaki iliskei (Samsun ili örneği) (Yüksek Lisans Tezi). Ondokuz Mayıs Üniversitesi Eğitim Bilimleri Enstitüsü, Samsun.

Akyüz, M. Y. (2002). Çağdaş okulda etkili liderlik. Ege Eğitim Dergisi, 1(2), 109-119.

Arslan, M. (2009). Yeni ilköğretim programmm uygulanmasinda ilkögrretim okulu yöneticilerinin ögretimsel liderlik rollerine ilişkin ögretmen görüsleri (Yüksek Lisans Tezi). Gazi Üniversitesi Sosyal Bilimler Enstitüsü, Ankara.

Arslanargun, E. (2011). Türkiye'de okul yönetimi ve atama yönetmelikleri. Education Sciences, 6(4), 2646-2659.

Avc1, A. (2015). Öğretmen algılarına göre okul müdürlerının liderlık stillerı. Hasan Ali Yücel Eğitim Fakültesi Dergisi, 12(2), 161-189.

Ay, G. ve Koç, H. (2014). Örgütsel adalet alg1sı ile örgütsel bağlllık düzeyi arasındaki ilişkinin belirlenmesi: öğretmenler üzerinde bir inceleme. İsletme Araștırmalar Dergisi, 6(2), 67-90.

Balyer, A. (2013). Okul müdürlerinin öğretimin kalitesi üzerindeki etkileri. Kuram ve Uygulamada Eğitim Yönetimi, 2(2), 181-214.

Bang, H., Ross, S. ve Reio, T. G. (2013). From motivation to organizational commitment of volunteers in non-profit sport organizations. The role of job satisfaction. Journal of Management Development, 32(1), 96-112.

Bayram, L. (2005). Yönetimde yeni bir paradigma: örgütsel bağlllik. Sayıștay Dergisi, 16(59), 125-39.

Becker, H. S. (1960). Notes on the concept of commitment. American journal of Sociology, 66(1), 32-40.

Bektaş, F., Çoğaltay, N. ve Sökmen, Y. (2014). Öğretmen algılarına göre okul müdürlerinin liderlik davranışının örgütsel bağlllık üzerindeki rolü. Uluslararası Türk Ĕ̈itim Bilimleri Dergisi. 2014(3), 122-130.

Beycioğlu, K. ve Aslan, B. (2012). Öğretmen ve yöneticilerin öğretmen liderliğine ilişkin görüşleri: Bir karma yöntem çalışması. Kuram ve Uygulamada Ë̆itim Yönetimi, 2(2), 191-223.

Beycioğlu, K., Köybaşı, F., Uğurlu, C. ve Özer, N. (2018). Okul liderliği ölçeği (OLÖ) geçerlik ve güvenirlik çalışması. Amasya Üniversitesi Ë̆itim Fakültesi Dergisi, 7(1), 21-42.

Bozdoğan, K. ve Sağnak, M. (2011). İlköğretim okulu müdürlerinin liderlik davranışları ile öğrenme iklimi arasındaki ilişki. Abant İžet Baysal Üniversitesi Ë̆itim Fakültesi Dergisi, 11(1), 137-145.

Bozkurt, S., Çoban, Ö. ve Çolakoğlu, M. (2020). Örgütsel güven düzeyi ve toksik liderlik davranışları ilişkisinde örgütsel bağlllı̆̆ın arac1 etkisi. Hacettepe Üniversitesi Ĕgitim Fakültesi Dergisi, 35 (3), 704-719.

Buchanan, B. (1974). Building organizational commitment: The socialization of managers in work organizations. Administrative Science Quarterly, 19(4), 533-46.

Buluç, B. (2010). İlköğretim okullarında bürokratik okul yapısı ile okul müdürlerinin liderlik davranışı arasındaki ilişki. Ë̈itim ve Bilim, 34(152), 71-86.

Buluç, B. ve Serin, M. K. (2012). İlköğretim okul müdürlerinin öğretim liderliği davranışları ile öğretmenlerin örgütsel bağll1ıkları arasındaki ilişki. Kuram ve Uygulamada Eğitim Yönetimi, 18(3), 435-459.

Büyüköztürk, Ş., Kılıç-Çakmak, E., Akgün, Ö. E., Karadeniz, Ş. ve Demirel, F. (2016). Bilimsel araștırma yöntemleri. Ankara: Pegem Akademi.

Cemaloğlu, N. (2007). Okul yöneticilerinin liderlik stillerinin farklı değişkenler açısından incelenmesi. Türk Eüitim Bilimleri Dergisi, 5(1), 73-112.

Cemaloğlu, N. ve Kılınç, A. (2012). Okul müdürlerinin liderlik stilleri ile öğretmenlerin örgütsel güven düzeyleri arasındaki ilişki. Mehmet Akif Ersoy Üniversitesi Ë̆itim Fakültesi Dergisi, 1(23), 132-156.

Çetin, F., Basım, H. N. ve Aydoğan O. (2011). Örgütsel bağlllı̆̆ın tükenmişlik ile ilişkisi: öğretmenler üzerine bir araştırma. Selçu Üniversitesi Sosyal Bilimler Enstitüsü Dergisi, 0(25), 61-70.

Çoban, D. ve Demirtaş, H. (2011). Okulların akademik iyimserlik düzeyi ile öğretmenlerin örgütsel bağlllığ1 arasındaki ilişki. Kuram ve Uygulamada Ë̆itim Yönetimi, 3(3), 317-348.

Çoban, Ö. (2021). Okul yöneticisinin liderlik özellikleri. N. Özdemir, S. Turan ve Ö. Çoban (Eds.), 21. yy. okullarmı yeniden düsü̈mek (ss. 45-68). Ankara: Pegem Akademi.

Çöl, G. (2004). Örgütsel bağlllık kavramı ve benzer kavramlarla ilişkisi. İs, Güc Endüstri İlişkileri ve İnsan Kaynaklar Dergisi, 6(2), 4-11.

Demïrtaş, H. (2010). Dershane öğretmenlerinde örgütsel bağlllık ve iş doyumu. İnönü Üniversitesi Eğitim Fakültesi Dergisi, 11(2), 177-206.

Durnalı, M. (2018). Öğretmenlere göre okul müdürlerinin teknolojik liderlik davranıslar ve bilgi yönetimini gerçeklestirme düzeyleri (Doktora Tezi). Hacettepe Üniversitesi Eğitim Bilimleri Enstitüsü, Ankara.

Durnalı, M., ve Akbaşlı, S. (2020). Okul müdürleri teknolojik liderlik davranışlarının okulda bilgi yönetiminin gerçekleşme düzeyine etkisi. Milli Ë̈̆tim Dergisi, 49(225), 23-54.

Erdaş, Y. (2009). Deniə̧li il merkę̧inde çalısan ögretmenlerin örgütsel bağhlık düzeyleri (Yüksek Lisans Tezi). Pamukkale Üniversitesi Sosyal Bilimler Enstitüsü, Denizli.

Erdem, M. (2010). Öğretmen algılarına göre liselerde iş yaşamı kalitesi ve örgütsel bağlılıkla ilişkisi. Kuram ve Uygulamada Ë̆itim Yönetimi. 4(4), 511-537. 
Erdoğdu, M. Y. ve Aydındağ, Z. (2013). Öğretmenlerin kurumsal özdeşleşme ve bağlılıklarının algılanan yönetici davranışları açısından incelenmesi. İstanbul Sabahattin Zaim Üniversitesi Sosyal Bilimler Dergisi, 1(2), 158-172.

Erdoğmuş, H. (2006). Resmî-özel ilk.̈̈gretim okullarmda çalı̧an yöneticilerin kişisel özellikleri ile örgütsel bağhlıklar arasındaki iliş̧i: (İstanbul örneği) (Yüksek Lisans Tezi). Marmara Üniversitesi Eğitim Bilimleri Enstitüsü, İstanbul.

Ergen, Y. (2009). Illkögretim okulu müdürlerinin ögretim liderlik davranıslarmm ögretmenlerin motivasyonu üzerindeki etkisi (Manisa ili örneği) (Yüksek Lisans Tezi). Celal Bayar Üniversitesi Sosyal Bilimler Enstitüsü, Manisa.

Ergün, H. ve Çelik, K. (2019). Örgütsel bağlllık ölçeği türkçe uyarlaması. Pamukkkale Üniversitesi Sosyal Bilimler Enstitüsü Dergisi, 34, 113-121.

Fidan, T., Ayyıldız, P., ve Kurt, T. (2021). Eğitim liderliği araştırmalarında deneysel desenlerin yeri. İ. Aydın, İ. Öztürk, T. Güner Demir, Ö. Erdemli, B. Toptaş (Yay. Haz.). Prof. Dr. Ali Balcr'ya armağan içinde. Ankara: Ankara Üniversitesi Yayınları.

Gökbulut, B., ve Turan, S. (2021). Exploring the link between principals visionary leadership and school effectiveness. International Journal of Education Technology and Scientific Researches, 6(14), 589-23.

Gören, T. ve Sarpkaya, P. Y. (2014). İlköğretim kurumlarında görev yapan öğretmenlerin örgütsel bağlllk düzeyleri (Aydın ili örneği). Marmara Üniversitesi Atatürk. Eğitim Fakültesi Ĕ̈itim Bilimleri Dergisi, 40(40), 69-87.

Gümüşeli, A. İ. (2001). Çağdaş okul müdürünün liderlik alanları. Kuram ve Uygulamada Eğitim Yönetimi, 28(28), 531548.

İnand1, Y. ve Özkan, M. (2006). Resmi ilköğretim okulları ve liselerde görev yapan yönetici ve öğretmenlerin görüşlerine göre müdürler ne derece öğretim liderliği davranışlar1 göstermektedir? Mersin Üniversitesi Ĕ̈itim Fakültesi Dergisi, 2(2), 123-149.

Kalay, M. (2015). İlkokul ve ortaokullarda görev yapan ögretmenlerin örgütsel bağhlık ve motivasyonlar arasindaki iliski (Bolu ili örneği) (Yüksek Lisans Tezi). Abant İzzet Baysal Üniversitesi Eğitim Bilimleri Enstitüsü, Bolu.

Karaca, M., Bayram, A. ve Harmanc1, Y. (2020). İnsan kaynakları yönetimi uygulamalarının örgütsel bağl1lık üzerindeki etkisi. MANAS Sosyal Araștırmalar Dergisi, 9(1), 199-208.

Karataş, S. ve Güleş, H. (2010). İlköğretim okulu öğretmenlerinin iş tatmini ile örgütsel bağlllı̆̆1 arasındaki ilişki. $U_{s ̧ s}$ Üniversitesi Sosyal Bilimler Dergisi, 3(2), 74-89.

Katz, D. ve Kahn, R. L. (1977). Örgütlerin toplumsal psikolojisi (Çev. H. Can ve Y. Bayar) Ankara: Türkiye ve Orta Doğu Amme İdaresi Enstitüsü Yayınları.

Kelley, R. C., Thornton, B., ve Daugherty, R. (2005). Relationships between measures of leadership and school climate. EDUCATION-INDIANAPOLIS THEN CHULA VISTA, $126(1), 17$.

Kilınçarslan, S. (2013). Okul yöneticilerinin liderlike stilleri ile ögretmenlerin örgütsel bağllhk düzeyleri arasindaki ilişkinin incelenmesi-İzmir ili Karabağlar ilçesi örneği (Yüksek Lisans Tezi). Okan Üniversitesi Sosyal Bilimler Enstitüsü, İstanbul.

Korkmaz, M. (2005). Duyguların ve liderlik stillerinin öğretmenlerin performansı üzerinde etkisi. Kuram ve Uygulamada Ë̆itim Yönetimi, 43(43), 401-422.

Kösterelïoğlu, M. ve Olukçu, E. (2019). Okul yöneticilerinin öğretimsel liderlik rolleri ile öğretmenlerin örgütsel Özdeșleşme düzeylerinin ilișkisi. Uluslararası Liderlik. Ë̆itimi Dergisi, 2(2), 31-45.

Kulu, M. (2020). Okul yöneticilerinin dağıtımo liderlik davranışlar ile öğretmenlerin mesleki topluluk düreyleri arasındaki ilişki (Yüksek Lisans Tezi). Karamanoğlu Mehmetbey Üniversitesi Sosyal Bilimler Enstitüsü, Karaman.

Kurşunoğlu, A., Bakay, E. ve Tanrıöğen, A. (2010). İlköğretim okulu öğretmenlerinin örgütsel bağlllık düzeyleri. Pamukkale Üniversitesi Ë̆itim Fakültesi Dergisi, 28(28), 101-115.

Leblebici, E. (2016). Ögrretmen algzlarna göre meslek liselerinde örgütsel imaj, örgüt kültürü ve örgütsel özdeşlesme arasindaki ilişkinin incelenmesi (Yükssek lisans tezi). Mevlana Üniversitesi Sosyal Bilimler Enstitüsü, Konya.

Madenoğlu, C., Uysal, Ş., Sarıer, Y. ve Banoğlu, K. (2014). Okul müdürlerinin etik liderlik davranışları ile öğretmenlerin iş doyumlarının örgütsel bağl1lıkla ilişkisi. Kuram ve Uygulamada Eğitim Yönetimi, 1(1), 47-69.

Mathieu, J. E., ve Zajac, D. M. (1990). A review and meta-analysis of theantecedents, correlates, and consequences of organizational commitment. Psychological Bulletin, 108(2), 171-93.

Memişoğlu, S. P (2003). Yeni liderlik yaklaşımları sşı̆̆ında eğitim örgütlerinde lider yöneticilere duyulan gereksinim. Abant İzet Baysal Üniversitesi Ë̆itim Fak̈ültesi Dergisi, 3(1), 87-97.

Mowday, R. T., Porter, L. W. ve Steers, R. M. (1982). Employee-organization linkages: The psychology of commitment, absenteeism, and turnover. San Diego, CA: Academic Press.

Nartgün, Ş. S. ve Menep, İ. (2010). İlköğretim okullarında görev yapan öğretmenlerin örgütsel bağlllı̆g ilişkin alg1 düzeylerinin incelenmesi: Șırnak/İdil örneği. Uluslararası İnsan Bilimleri Dergisi, 7(1), 288-316.

Nartgün, Ş. S., Limon, İ. ve Dilekçi, Ü. (2020). The relationship between sustainable leadership and perceived school effectiveness: The mediating role of work effort. Bartm University Journal of Faculty of Education, 9(1), 141-154.

Okçu, V. (2014). Ortaöğretim Okulu yöneticilerinin etik liderlik davranışları ile öğretmenlerin örgütsel bağl1likları arasındaki ilişki. Kuram ve Uygulamada Eğitim Yönetimi, 20(4), 501-524.

Özbek, M. F. (2011). Örgüt içerisindeki güven ve işe yabancılaşma ilişkisinde örgüte uyum sağlamanın arac1 rolü. Süleyman Demirel Üniversitesi İktisadi ve İdari Bilimler Fakültesi Dergisi, 16(1), 231-248.

Özdemir, N. (2019). Principal leadership and students' achievement: Mediated pathways of professional community and teachers' instructional practices. KEDI Journal of Educational Policy, 16(1), 81-104. 
Özsoy, S., Ergül, Ş. ve Bayık, A. (2001). Bir yüksekokul çalışanlarının kuruma bağlılık durumlarının incelenmesi. Ege Üniversitesi Hemşirelik Fakültesi Dergisi, 17(3), 1-16.

Sezgin, F. (2010). Öğretmenlerin örgütsel bağlllı̆̆ının bir yordayıcısı olarak okul kültürü. Eğitim ve Bilim, 35(156), $142-$ 159.

Surat, A. ve Polat, H. (2020). Örgütsel bağlllığın kişisel özelliklere göre farklllıklarının incelenmesi: Adana ili alan çalışması. IBAD Sosyal Bilimler Dergisi, 20(6), 321-343.

Şentürk, C. ve Sağnak, M. (2012). İlköğretim okulu müdürlerinin liderlik davranışları ile okul iklimi arasındaki ilişki. Türk Ĕ̈itim Bilimleri Dergisi, 10(1), 29-43.

Tahaoğlu, F. ve Gedikoğlu, T. (2009). İlköğretim okulu müdürlerinin liderlik rolleri. Kuram ve Uygulamada Ĕ̈itim Yönetimi, 15(58), 274-298.

Tarter, C. J., Hoy, W. K. ve Bliss, J. (1989). Principal leadership andorganizational commitment: The principal must deliver. Planning and Changing, 20(3), 131-140.

Terzi, A. R. ve Kurt T. (2005). İlköğretim okulu müdürlerinin yöneticilik davranışlarının öğretmenlerin örgütsel bağlilığına etkisi. Milli Ĕgitim Ü̧ Aylı Eğitim ve Sosyal Bilimler Dergisi, 33(166), 98-111.

Tsui, K. T., ve Cheng, Y. C. (1999). School organizational health and teacher commitment: A contingency study with multi-level analysis. Educational Research and Evaluation, 5(3), 249-268.

Turan, S., Polatcan, M. ve Cansoy, R. (2020). Technology Leadership in Turkish Schools: A Systematic Review. In Durnal1, M., (Ed.) (2020), Utilizing technologies, knowledge and smart systems in educational administration and leadership (pp. 59-79). Hershey, PA: IGI Global, doi:10.4018/978-1-7998-1408-5.ch001

Uğurlu, C. T. ve Üstüner, M. (2011). Öğretmenlerin örgütsel bağlllık düzeylerine yöneticilerinin etik liderlik ve örgütsel adalet davranışlarının etkisi. Hacettepe Üniversitesi Eğitim Fakültesi Dergisi, 41(41), 434-448.

Yazar, F. ve Özutku, H. (2019). Psikolojik sermayenin örgütsel bağlllık üzerindeki etkisine yönelik bir araştırma. Afyon Kocatepe Üniversitesi İktisadi ve İdari Bilimler Fakültesi Dergisi, 21 (2), 70-81.

Yıldız, K. (2013). Örgütsel bağlllık ile örgütsel sinizm ve örgütsel muhalefet arasındaki ilişki. Electronic Turkish Studies, $8(6), 853-879$.

Yılmaz, A. ve Ceylan, Ç. B. (2011). İlköğretim okul yöneticilerinin liderlik davranış düzeyleri ile öğretmenlerin iş doyumu ilişkisi. Kuram ve Uygulamada Ë̆itim Yönetimi, 17(2), 277-294.

Yılmaz, K. (2020). Liderlik: Kuram-Araștırma-Uygulama. Ankara: Pegem Akademi Yayıncılık.

Yörük, S. ve Sağban, Ş. (2012). Okul müdürlerinin kültürel liderlik rollerinin öğretmenlerin örgütsel bağlllı düzeyine etkisi. Electronic Turkish Studies, 7(3), 2795-2813.

\section{EXTENDED ABSTRACT}

Concepts such as creativity, risk-taking, and values are at the forefront in the content of leadership there are contents such as hierarchy, discipline, and control based on the management concept. The issue of directing people towards determined goals gains importance (Arslan, 2009). Even though leadership has been the subject of research in various fields of social sciences, there is no consensus on its definition. One of the reasons for the emergence of this situation is that leadership is examined in many different fields and its priority in each field is different. The changes experienced in the educational processes necessitate a change in the leadership roles of school principals. Traditional leadership roles based on a top-down hierarchical management approach have shifted from the axis of the leader and those who follow it to the sharing of leading-collaborative employees with the changing processes (Beycioğlu, \& Aslan, 2012, p. 195).

Parents have now begun to take on more roles in matters such as choosing the school their children will attend, participating in the administration of the school, and helping their children with their education. This change of understanding has also brought about changes in traditional school-home, parent-teacher relationships, and has made it necessary to develop and implement more flexible, participatory, models that allow mutual interaction (Gümüsseli, 2001, p. 536). Therefore, a school principal has to lead not only the school but also the stakeholders outside the school.

The changes taking place in the educational journey also manifested themselves in the role of the teacher. The teacher model, which transmits information unilaterally, has been replaced by leader teachers who guide the student. This perspective has brought about a change from subject-based curricula to student-centered curriculums, which creates an active student model instead of a model that keeps students passive (Gümüşeli, 2001, p. 534). In today's schools, teachers' expertise is not only considered to be sufficient in their field but also teachers are expected to deal with students' behavioral and social problems. Teachers' job satisfaction and teaching motivation can be considered as a prerequisite for effective education and training in schools. To increase their success, teachers must spend their energy on students in their classes. A school principal who wants to make his school effective and successful has to show efficiency as a leader (Akyüz, 2002, p. 111). 
In today's schools, the notion that effective leaders may be needed instead of the traditional school principal understanding to prepare children for the future with the available possibilities finds support in the leadership epistemological movement. It is understood that school principal leadership has progressed and expanded in theory and practice at the point of becoming the dominant paradigm in this movement. As a consequence of this status quo, the leadership role of school principals is considered to be important. Effective principals are expected to display these leadership roles to achieve the goals of their schools at a high level. Within the scope of these efficiencies based on leadership roles, increasing the motivation of teachers by creating appropriate educational environments and increasing teachers' commitment to the organization by sharing school-related decisions with teachers can be given as examples.

At this point, it can be emphasized that the problem of teachers' commitment to the school is in an actual situation in the educational sciences community today. It can be stated that this issue is important in terms of the efficiency and effectiveness of the school, which is the mainstream occupation. It may be useful to examine the school and educational elements to increase teachers' school engagement in terms of ensuring integrity in education. Based on this importance, the case problem of examining the organizational commitment of teachers and the leadership of school principals was determined in the context of this study. The following questions were sought in the study.

1. What are teachers' perceptions of school principals' leadership behaviors and their organizational commitment levels?

2. Do teachers' perceptions of the leadership behaviors of school principals show statistically significant differences according to their gender?

3. Do teachers' perceptions of the leadership behaviors of school principals show statistically significant differences according to their professional seniority?

4. Do teachers' organizational commitment levels show statistically significant differences according to their gender?

5. Do teachers' organizational commitment levels show statistically significant differences according to their professional seniority?

6. Is there a relationship between leadership behaviors of school principals and teachers' organizational commitment?

7. Do leadership behaviors of school principals predict teachers' organizational commitment?

In the first sub-problem of the study, it was found that the average of teachers' answers to this questionnaire was at the level of "agree". In line with this result, it is seen that teachers in the study group have a positive and high level of perceptions and organizational commitment towards the leadership behaviors of school principals.

In the second sub-problem of the study, it was found out that male teachers' perceptions of school principals' leadership behaviors are higher than female teachers. In the third sub-problem of the study, teachers' perceptions of school principals' leadership behaviors did not reveal a statistically significant difference according to their professional seniority. In the fourth sub-problem of the study, it was found out that there was no significant difference between teachers' organizational commitment levels according to the gender variable.

In the fifth sub-problem of the study, although teachers with 1-5 years of professional seniority show a higher level of organizational commitment than other teachers, their organizational commitment levels do not reveal a statistically significant difference according to their professional seniority. In the sixth problem of the study, it was seen that there was a positive and moderate relationship between school principals' leadership behaviors and organizational commitment. In the seventh sub-problem of the study, the leadership behaviors of school principals predict teachers' organizational commitment positively and significantly. 